\title{
Australia as a Powerbroker on Refugee Protection in Southeast Asia: The Relationship with Indonesia
}

\author{
SUSAN KNEEBONE
}

\begin{abstract}
Using the example of Australian-Indonesian cooperation on deterrence of asylum seekers in transit through Indonesia to Australia, this article challenges the view that Australia is a regional hegemon. It does this through two main methods. First, it engages in a close analysis of the shifting relationship between the two countries on refugee and asylum-seeker issues through different periods since 2001 to 2016. This demonstrates that the relationship is in fact more nuanced than previously suggested by other scholars. Second, it refers to Thomas Pedersen's political concept of "cooperative hegemony," which focuses upon "ideationalinstitutional realism" as a lens through which to view regional co-operation. It analyzes the institutional nature of the Australian-Indonesian cooperation relationship in the Southeast Asian context, to demonstrate that Australia has not established itself as a model of "cooperative hegemony."
\end{abstract}

\section{Résumé}

En prenant l'exemple de la coopération australo-indonésienne pour dissuader les demandeurs d'asile traversant l'Indonésie sur la route de l'Australie, cet article conteste le point de vue d'une hégémonie régionale de l'Australie par un travail en deux temps. Il rapporte tout d'abord une analyse approfondie de la relation ambiguë qu'ont entretenue les deux pays sur la question des réfugiés et des demandeurs d'asile d'une période à l'autre entre 2001 et 2016, et démontre que cette relation est en pratique plus nuancée que celle auparavant décrite par d'autres universitaires. Il fait ensuite référence au concept politique d' "hégémonie coopérative" de Thomas Pedersen, qui met l'accent sur le "réalisme idéationnel-institutionnel» en tant que prisme d'analyse de la coopération régionale, pour examiner la nature institutionnelle de la relation de coopération quentretiennent l'Indonésie et l'Australie dans le contexte du Sud-Est asiatique et ainsi démontrer que cette dernière ne sest pas imposée comme modèle d' "hégémonie coopérative».

\section{Introduction}

Ithough Australia is keen to present itself as a leading power or hegemon and "norm entrepreneur" on 1 refugee and asylum-seeker issues in the Asia-Pacific region, I argue that this self-perception is challenged by a close examination of Indonesia-Australia cooperation on these issues. There are two strands to this argument. First, relying upon the legal concept of global refugee protection, I argue that Australian-Indonesian cooperation is not explained primarily by power asymmetry and acquiescence with Australia's "burden-shifting" measures. Second, I refer to Thomas Pedersen's political concept of "cooperative hegemony," which focuses upon "ideational-institutional realism" as a lens through which to examine arrangements in regional co-operation. ${ }^{1}$

The regime of global refugee protection is conceived as a "global public good" under which states share the burden of such protection. ${ }^{2}$ The concept of state burden or responsibility sharing underlies the Refugee Convention, ${ }^{3}$ as noted in its Preamble and Article 35, and assumes "an expectation of reciprocity" between states. ${ }^{4}$ However the current reality 
is that the burden of refugee protection is unevenly shared between states in the Global North and South, as most asylum seekers remain in countries close to their homes. This is largely a consequence of states in the Global North practising increasingly diverse non-entrée measures. There is a view that the current global response to refugee protection, which includes "cooperative deterrence and non-entrée policies,"5 reflects a "North-South divide" in which developed states conscript "less developed countries to act in ways that provide a critical support to the developed world's migration control project." 6 This argument assumes an asymmetry in power relationships, whereby cooperating states are persuaded to act in the interests of the developed states through a variety of mechanisms, including financial incentives, the provision of training, or deployment of officials.

In the case of Australia-Indonesia cooperation it has been argued that the relationship reflects an "incentivised policy transfer," 7 secured through substantial financial and diplomatic incentives. I argue that the metaphor of "incentivised policy transfer" is an incomplete explanation for Indonesia's apparent cooperation with Australia's deterrent policies.

A second strand of my argument is to focus on the role of states and institutional structures affecting the AustraliaIndonesia relationship. Two regional institutions are potential agents of "cooperative hegemony": $\operatorname{ASEAN}^{8}$ and the Bali Process. ${ }^{9}$ Indonesia is a member state and leading player of ASEAN; Australia has many trading partnerships and agreements with ASEAN ${ }^{10}$ but is not a member state. On the other hand, Australia and Indonesia co-chair the Bali Process, which also reflects a bilateral arrangement between the two countries.

In this article I show that ASEAN's conflicted response to refugees is reflected in Indonesia's national response. As I have previously argued, the Bali Process has thus far failed to establish itself as either a leading regional institution or as "norm entrepreneur" of refugee protection. ${ }^{11}$ I contend that the Australia-Indonesia cooperation relationship mirrors the "institutional space"12 created by the Bali Process, rather than being a model of "cooperative hegemony."

To make the argument against Australia's role as a regional hegemon, I examine three periods of the Australia-Indonesia relationship: from 2001 to 2008 (acquiescence with Australian policies of securitization of refugee and asylum-seeker issues); 2008 to 2013 (Indonesian prevarication in the face of increasingly aggressive Australian policies); 2013 to the present (Indonesia turns to the region during the 2015 Andaman Sea crisis).

\section{Contextual Background}

First some context for the discussion is needed. Indonesia and Australia have a shared history in refugee protection arising from the Comprehensive Plan of Action (CPA) for
Indo-Chinese Refugees, ${ }^{13}$ which operated for over two decades from $1975 .{ }^{14}$ This led to lasting legacies on refugee policy, which can be described briefly. In Australia it led to a clear preference for resettlement as a "durable solution" over territorial asylum-seeking. ${ }^{15}$ Indonesia's role in refugee processing was a reluctant one; nevertheless it cooperated in the CPA and tolerated the screening of refugees on Galang Island under UNHCR supervision. ${ }^{16}$ In particular, a presidential decree recognizing the need for refugee protection was issued in 1979. ${ }^{17}$ As this article demonstrates, Indonesia's role in refugee protection is still a conflicted mixture of tolerance and principled recognition, although it has allowed deterrent practices to develop.

There are two important contextual features of the Indonesia's situation vis-à-vis refugees. The first is that as the result of its geographical position, in contrast to other countries in the region, Indonesia is largely a transit country for Australia-bound refugees, including those coming from Malaysia to Indonesia. The route through Malaysia developed in response to the introduction of a stricter visa regime in Indonesia in the 2011 law (described below), which in turn led to more smuggling from Malaysia to Indonesia. ${ }^{18}$ Indonesia therefore has a shared or mutual interest with Australia in controlling both in- and out-bound migration.

Second, unlike Malaysia and Thailand (both players with Indonesia in the Andaman Sea crisis of 2015), Indonesia is not primarily a destination country with large protracted refugee populations in need of "durable solutions." Currently Indonesia hosts relatively few (approximately 14,000) asylum seekers and refugees, which nevertheless represent a substantial increase in the last few years as a result of Australia's "containment" policies, explained below. Thailand by contrast has 105,935 refugees living in nine long-established refugee camps in four provinces along the Thai-Myanmar border. ${ }^{19}$ There are urban-based refugees too, albeit in much smaller numbers. At the end of 2015, UNHCR in Thailand had registered 1,830 new urban arrivals. ${ }^{20}$ In 2015, record numbers of refugees arrived in Malaysia, mostly as a result of the Andaman Sea crisis. As of June 2016, there were 150,700 refugees and asylum seekers registered with UNHCR in Malaysia. ${ }^{21}$

Like Indonesia, neither Malaysia nor Thailand is a party to the Refugee Convention, and indeed it is suggested they have rejected the Convention as a European instrument. A legacy of the CPA (in which all three countries participated) is that countries in Southeast Asia perceive refugee resettlement as an obligation of the "international community." Within the region, refugees overlap with irregular migrant workers and stateless persons. As a category of forced migrant, the "refugee" is not well understood. ${ }^{22}$

All three countries are part of the Bali Process and member states of ASEAN. ASEAN takes a somewhat ambiguous 
approach to refugees. ${ }^{23}$ On the one hand, refugees are included in the ASEAN Political-Security Community (APSC) pillar of the ASEAN Community. The APSC subscribes to "a comprehensive approach to security, which acknowledges the interwoven relationships of political, economic, socialcultural and environmental dimensions of development." 24 Within the APSC refugees are constructed, both within a national security paradigm as "victims of conflict," and as beneficiaries of a "human security" approach, which recognizes the risks to regional harmony arising from gaps in economic development.

On the other hand, refugee rights are provided in the ASEAn Human Rights Declaration (AHRD). ${ }^{25}$ The AHRD, Article 2, provides guarantees for the very freedoms that are at the base of the need for refugee status in the region, namely freedom from discrimination on the basis of "race, gender, age, language, religion, political or other opinion, national or social origin, economic status, birth, disability or other status." Article 14 of the ADHR enshrines the principle of nonrefoulement when it states without qualification, "No person shall be subject to torture or to cruel, inhuman or degrading treatment or punishment." Articles 15 and 16 refer to the right to freedom of movement and specifically to the right to seek asylum.

As stated, Indonesia's response to Australia on refugee issues is largely referenced to its position as a transit country. However, Indonesia has long-standing experience with "forced" migration as internal migration and as outwardbound labour migration, which overlaps with the issue of human trafficking, which it has been addressing since at least 2002. Indonesia is also considered to be a leader within ASEAN, particularly in the APSC area, as a result of its strategic location in the Straits of Malacca, and its interest in regional and maritime security. ${ }^{26}$

Within the region, Australia has concluded other bilateral agreements that extend Australia's deterrent policies to asylum seekers to processing in off-shore sites. This is both a legacy of and the continuation of a policy of discouraging on-shore or "spontaneous" asylum seekers, which began from Australia's experience with the CPA. During the 1990 os Australian policies became increasingly focussed on containing refugees in transit to Australia in offshore locations. The "Pacific Strategy," as it was initially termed, arose from bilateral relationships recorded in memorandums of understanding (Mous) between Australia and Nauru and Australia and Manus Island (Papua New Guinea). It involved the interdiction and transfer of asylum seekers by the Australian Navy to "safe third countries," which were in reality cashstrapped Pacific Islands willing to enter into arrangements with Australia. Under these Mous the Australian government directed and financed the detention and processing of asylum seekers in offshore locations. In this period Australia "externalized" its border control through the positioning of airline liaison officers (ALOS) ${ }^{27}$ in Southeast Asia and provision of Australian Federal Police (AFP) training on people smuggling. ${ }^{28}$ For similar motives, Australia was developing a relationship with Indonesia, to which I now turn.

\section{Indonesian Pragmatism 2001-2008: Acquiescent Protection and Securitization}

Australia's Pacific Solution I, which operated in 2001-8, was a seemingly ad hoc response to the arrival of a Norwegian registered container ship, the MV Tampa, in Australian waters with a cargo of 433 asylum seekers in transit from Indonesia. This staged event, which took place in late August 2001 on the eve of an Australian federal election, ${ }^{29}$ ensured the re-election of Prime Minister John Howard and enabled the passage of a suite of legislation that established offshore processing. ${ }^{30}$ Far from being a spontaneous gesture, the creation of the Pacific Solution was a response to a spike in boat arrivals from Indonesia in the eighteen months leading up to early 2001. The majority of these arrivals were part of the "Afghan diaspora" of 2001 when an estimated 900,000 people fled Afghanistan.

Pacific Solution I was directed at asylum seekers who had made "secondary movements," mainly from Indonesia, although in the period before the Tampa incident the numbers were declining and continued to decline in 2001-8. Moreover, Australia and Indonesia were establishing a cooperative arrangement known as the Regional Cooperation Model 2000 (RCM), which was later formalized through the Bali Process as the Regional Cooperation Arrangement (RCA).

At the time of the Tampa incident, the apparent unwillingness of President Megawati Sukarnoputri to take a phone call from the Australian prime minister provided a snapshot of the relationship between the two states. The Australian authorities had implied that the asylum seekers were Indonesia's responsibility by requesting the captain of the Mv Tampa to return them to Indonesia. At the time Indonesia was coping with its own internal "refugee" or displaced population of 1.3 million people.

The number of persons held under the Pacific Solution I peaked in February 2002 at 1,550. It was originally intended that the asylum seekers held on Nauru and Manus Island would be processed within six months of their arrival. But the processing was painfully slow as the government waited for the situations in the countries of origin to stabilize, presumably so that the asylum seekers could be returned home. ${ }^{31}$ However, by May 2005 65.5 per cent of the Pacific Solution I asylum seekers had been resettled (mainly in Australia and New Zealand), and Pacific Solution I was wound back. ${ }^{32}$ The 
eventual demise of Pacific Solution I was bound up with the defeat of the Liberal-National Party Coalition (the Coalition) by the Rudd Labor government in the November 2007 election. ${ }^{33}$ In February 2008 Pacific Solution I was wound up..$^{34}$

During this period there were two countervailing developments in the Australia-Indonesia relationship on refugee protection. The first was the endorsement of the RCA, which cemented refugee protection in Indonesia, and the second was the creation of the Bali Process, which was focused on irregular migration. At the same time, there were developments in Indonesia's laws on refugee protection that ran counter to Australia's efforts under the Bali Process. These developments suggest a conflicted Indonesian approach to refugee protection.

The Regional Cooperative Arrangement and the Bali Process Australia-Indonesia cooperation on asylum seekers dating from the late 1990s was formalized through the Bali Process as the Regional Cooperation Arrangement (RCA). The RCA also describes the roles of the Intergovernmental Organisation for Migration (IOM) and the UNHCR. Thus the RCA is a bilateral agreement between two states that involves a non-state actor (the UNHCR) and an intergovernmental actor. Under this agreement IOM and UNHCR act in place of the two states, Australia and Indonesia. That is, Indonesia is willing to delegate its role to non-state/interstate institutions, namely UNHCR and IOM. Australia, on the other hand, has the practical necessity to work through IOM in Indonesia.

The RCA requires the Indonesian government to intercept and detain "Australia bound" "irregular migrants," to notify IOM, which is to provide advice and assistance (particularly about "voluntary return"), and then (if needed) UNHCR will assess their claims. Under the RCA it is envisaged that Indonesian officials will refer asylum seekers to IOM for "case management and care," who then refer them to UNHCR to make asylum claims, if they express a wish to do so. UNHCR performs refugee status determinations (RSD) because Indonesia is not a party to the Refugee Convention. IOM as an intergovernmental body is funded by interested governments and in particular by the Australian government in relation to its activities in Indonesia.

The RCA prioritizes the role of IOM. Within Indonesia IOM has greater visibility (it has more offices than UNHCR, which is often co-located with IOM) ${ }^{35}$ and arguably more power because of its role under the RCA as the first port of call. Whereas IOM has many offices, UNHCR has only one official office in Jakarta in central Java.

Initially Indonesia tolerated the presence of asylum seekers on its territory (the RCA itself speaks to that, as do the legislative policies detailed below), but from 2004 onwards there was an increasing emphasis on detention, which involved IOM and Australian funding. Initially asylum seekers registered with UNHCR, but falling outside the scope of the RCA, were not usually detained, but had their whereabouts monitored by UNHCR. ${ }^{36}$ After the commencement of the RCA the focus of IOM's role shifted from Australianfunded accommodation in five designated areas ${ }^{37}$ to detention. A second bilateral arrangement between Indonesia and Australia commenced in 2007. This was the Management and Care of Irregular Immigrants Project, funded by Australia, which led to the creation of more detention facilities, managed by IOM. ${ }^{38}$

Further Australia-Indonesian cooperation in this period promoted a securitized approach to irregular migration. In 2006-7 Australia supported the implementation of the Enhanced Cekal System (ECS) - a border alert system that would "assist Indonesia to detect the movement of terrorists and other transnational criminals." 39 Australia also concluded an MOU with Indonesia on cooperation on migration and border control management. ${ }^{40}$ The impact of the Bali Process (which formally began in 2002, met again in 2003, then not again until 2009) ${ }^{41}$ was mainly in the area of capacity-building in Indonesia. For example, in a speech made in 2004 by Caroline Millar, the Australian "ambassador for smuggling issues" under the Bali Process, ${ }^{42}$ it was explained that Australia was assisting Indonesia to draft anti-smuggling laws, and providing capacity-building "to deal with illegal immigration in areas such as border management, visa systems and the verification of identity and nationality." 43

The result of this collaboration was a law that Indonesia introduced in 2011-Law 6/2011 "Concerning Immigration" discussed below, which introduced new anti-smuggling laws. In her speech Millar referred to Australia's "strong political support in the region." She mentioned that it promoted its agenda "through capacity-building activities and practical workshops," and cooperation on addressing people smuggling and trafficking. Her speech made it clear that Australia saw itself as a hegemonic force in the region, acting through the Bali Process. However, the evidence suggests that the Bali Process had limited regional impact in this period beyond the bilateral relationship. ${ }^{44}$ Although Indonesia is a co-chair of the Bali Process, during this period it did not assert its role. However, at the 2003 meeting the Indonesian minister for foreign affairs made a rare statement acknowledging the protection needs of refugees. 45 This statement is consistent with the RCA and Indonesian legislative policies that recognize the status of "refugee."

\section{Indonesian Legislative Policies and State Responsibility} Indonesia was aware of refugee protection principles from the 1950s. A 1956 circular letter recognized the need for protection of "political" refugees. ${ }^{46}$ Further Indonesia's 
participation in the post-Bandung Asian-African Legal Consultative Organisation from 1956 (and in the 2001 reformulation of its principles) demonstrates its awareness of broader principles of refugee protection, both as Convention refugees and under the expanded refugee definition. ${ }^{47}$ Yet despite recognition of refugees in its laws and policies, Indonesia has not become a party to the Refugee Convention, partly because it fears the "pull factor" of such a move, ${ }^{48}$ but also because of concerns about the cost of refugee protection.

Some commentators suggest that the CPA experience had some impact on the Indonesian state, as UNHCR started "awareness-raising" about refugee protection in Indonesia in 1981. Indeed laws dating from 1998 recognize asylum seek ers. ${ }^{49}$ The Constitution of the Republic of Indonesia and laws recognize asylum seekers, although not in the same terms of the Refugee Convention definition. They create two categories of refugees: political and "foreign" refugees. They are framed under two concepts: those who have human rights needs and those who need the protection of another country. The Constitution, Article 28G(2), recognizes the right to freedom from torture and to obtain "political asylum from another country." Law no. 37 of 1999 on Foreign Relations incorporates three articles relating to "foreign refugees." For example, Article 26: "The granting of asylum to foreign nationals shall be exercised in accordance with national legislation taking into account international law, custom and practice" (my emphasis).

Article 27 contains provisions requiring the president to determine policy on "(foreign) refugees" and to create a presidential decision. Moreover Law No. 39 of 1999 on Human Rights contains the right to political asylum as set out in the Constitution.

Indonesia is a party to the two general human rights instruments that recognize the right to freedom from torture and inhuman and degrading treatment..$^{\circ}$ Thus it is aware of international human rights obligations owed to asylum seekers.

The UNHCR's role under the RCA is recognized in administrative policies that acknowledge the non-refoulement principle, which is contained in Indonesia's Constitution and its laws. In 2002 a circular "regarding Procedures regarding Aliens Expressing Their Desire to Seek Asylum or Refugee Status" was created..$^{11}$ Subsequently the 2010 Directive of the Director General of Immigration ${ }^{52}$ was issued, to provide for security of status if UNHCR has affirmed the status of an asylum seeker through a RSD procedure. The 2010 directive ensures that refugees and asylum seekers have access to UNHCR, and allows them to stay temporarily in the country until their refugee status can be confirmed and appropriate solutions can be found for them. It affirms the effect of the 2002 circular and the terms of the RCA described above. Although the 2010 directive is titled an instrument "Regarding Handling of Irregular Migrants," defined as persons who "subsequently declare themselves as asylum seekers and refugee(s)," it confirms the non-refoulement obligation.

It is clear then that Indonesia was and is well aware of its international obligations to asylum seekers/refugees. Although not a party to the Refugee Convention, it has long acknowledged underlying international principles and its obligations in its Constitution and its laws. Soeprapto, writing in 2004,53 says that until 2000 the response of the government to accession to the Refugee Convention was "encouraging." 54 But the current Indonesian government has shelved plans to accede to the Convention, despite positive indications in the first part of the twenty-first century. 55

In this period the Indonesian response to Australian intervention was pragmatic and compliant with securitization, but this was tempered by tolerance and "humanitarian" refugee protection for asylum seekers transiting through Indonesia. However when Australia granted asylum to a group of Indonesian West Papuan refugees in 2006, Indonesia was outraged. $5^{6}$ This period coincided with an initial increase and then decline in the number of asylum seekers transiting to Australia. In the securitized period from 2008 onwards when numbers increased once more, a more complex relationship developed.

\section{Indonesian Prevarication 2008-2013: Conflicted State Responses}

In the period from 2008 to 2013 , in an attempt to stem the increasing arrival of asylum seekers from Indonesia (and Sri Lanka) to Australia, first the Rudd and then the Gillard Labor government focused upon "breaking the people smugglers' business model." 57 With the return of the Coalition in 2013 and the creation of Operation Sovereign Borders (оsв) in September of that year, the rhetoric shifted to "stopping the boats." Under osB, in increasingly bold unilateral measures that breach international law, Australia has exploited its impunity from external forums. Australia has practised interdictions, turn-back and tow-back policies of dubious legality under international law, ${ }^{58}$ which have increasingly angered Indonesian authorities. 59 There are now many examples of the "illegality" of Australia's policies under international law. ${ }^{60}$ During this period, relations between Australia and Indonesia were strained by incursions into its waters. In November 2013 Indonesia suspended cooperation on migrant smuggling as a result of tensions arising from Australia's osB. ${ }^{61}$ In other incidents Australian officials paid Indonesian fishermen to transport asylum seekers back to Indonesian shores. ${ }^{62}$

\section{IOM and UNHCR: Challenging Roles}

In this period, as a result of Australian influence, Indonesia moved to a seemingly less tolerant approach, framing asylum 
seekers as illegal immigrants, and acceding to creation of detention facilities. ${ }^{63}$ This change has affected the roles of IOM and UNHCR. IOM has been the recipient of increased funding, whereas UNHCR funding has had to stretch further to cope with increasing numbers of asylum seekers stuck in transit in Indonesia. This resulted from the announcement in November 2014 that Australia would no longer resettle asylum seekers transiting from Indonesia. As there has been substantial increase in the number of asylum seekers in Indonesia, UNHCR struggles to keep up with the demand for processing of claims, with waiting times increasing.

Australia funds both the UNHCR and IOM, but it appears that IOM receives more funding than UNHCR for its activities in Indonesia. ${ }^{64}$ For example during 2008-9, Australia allocated:

- $\$ 807,727$ to UNHCR in Indonesia for protection capacity-building activities;

- $\$ 1,600,000$ to IOM for interpreting services for displaced persons in Indonesia;

- $\$ 386,000$ to IOM for educational and social services for refugees and irregular migrants in Indonesia. ${ }^{65}$

The Australian-funded increase in Indonesia's detention capacity has been matched by an increased tendency of Indonesian officials to detain (consistent with the new laws described below).

In 2014, according to IOM there were thirteen Immigration Detention Centres in thirteen provinces, operating under "arbitrary rules." 66 In 2015 UNHCR added that there were twenty further temporary detention facilities and 4,511 detainees. UNHCR reported that it had intervened in 856 cases to secure release from detention of vulnerable people (such as pregnant women and young children). It also reported that a number of asylum seekers in the community self-report for detention because they are unable to support themselves (asylum seekers are not permitted to work). Both IOM and UNHCR report severe overcrowding in detention facilities in Indonesia.

From 2010 IOм has been funded by Australia to run Public Information Campaigns (PICS), which are basically aimed at deterring Indonesian coastal communities from becoming involved in people smuggling. The PICs depict asylum seekers as "illegals" and invoke religious principles and deploy religious leaders to conceptualize people-smuggling as a sin. ${ }^{67}$ According to an IOM evaluation of a PIC, it led to a "radical shift in public opinion regarding the social and economic impact of people smuggling ... from one of general acceptance/tolerance ... to one of virtually unanimous rejection of people smuggling." ${ }^{68}$ An alternative view of the effect of the PICs is that they lead to practices that involve surveillance by members of the community, that is, statesociety "border-control." 69

\section{Legislative Response: The Dubious Effect of People- Smuggling Laws}

The result of the Australia-led capacity-building described above was a new law that Indonesia introduced in 2011-Law 6/2011 "Concerning Immigration" - which replaced the 1992 law. The 1992 law had justified the regulation of the "traffic of people" as "one manifestation of sovereignty as an independent legal state based on the rule of law." It imposed a requirement on "foreign nationals" to possess a visa (Article 6) but made no specific provision for asylum seekers or refugees. As Crouch and Missbach point out, ${ }^{70}$ it contained a number of provisions that could be and were used against "irregular" migrants and people smugglers.

Indonesia's Law 6/2011 focuses on irregular migration and the creation of smuggling offences. The preamble to this new law acknowledges that "today's global development drives greater mobility of people in the world ... protection and promotion of the human rights are required." Yet Law 6/2011 is designed to make asylum seekers "irregular." Graeme Hugo found that 84 per cent of asylum seekers entered Indonesia illegally because they could not comply with the legal immigration requirements. ${ }^{71}$ Thus Australia "exported" its policies of preventing movement of asylum seekers, as well as detention, to Indonesia.

However, the deterrent effect of the anti-smuggling laws is debatable. ${ }^{72}$ They have been used mainly to prosecute "low-level" criminals, and the sentences imposed have been lenient. ${ }^{73}$ There is evidence that in the Indonesian context of "porous borders," a range of factors results in "less than efficient border control," and the anti-smuggling law leads to practices (as do the PICs) that involve surveillance by members of the community. ${ }^{74}$ Corruption is rife, and the law arguably has a corrupting effect on the rule of law as members of the community are encouraged to "dob in" irregular migrants. Barker points out that a number of people convicted for smuggling under the legislation were themselves former asylum seekers "drawn into people smuggling" while in that situation in Indonesia. ${ }^{75}$

It seems that the effect of Australian anti-smuggling policy vis-à-vis Indonesia has had the effect of "commodifying" refugees/asylum seekers ${ }^{76}$ through the creation of a detention "industry" and by putting a price on asylum seekers in the minds of the community. This is in conflict with Indonesian laws and policies on protection of asylum seekers.

\section{9: A Watershed Year-Revival of the Bali Process and Cracks in the Australia-Indonesia Relationship}

While Indonesia increasingly securitized its response to asylum seekers and simultaneously tolerated UNHCR's protection work on its soil, the formal Bali Process lay dormant from 2003. But in April 2009 the Third Bali Regional Ministerial 
Conference (BRMC) was convened in response to increasing tensions in the region, following an increase in post-conflict asylum seekers from Sri Lanka and Pakistan. At this time, there was also concern about the treatment of Rohingyas fleeing from Myanmar. ${ }^{77}$ Following the Third BRMC, a Regional Immigration Liaison Network and a Regional Cooperation Framework (RCF) concept were developed and endorsed by ministers at the fourth BRMC in 2011. Simultaneously, the UNHCR and IOM were incorporated more closely into the Bali Process, in particular to advance the RCF concept, and the establishment of a Regional Support Office to "support and strengthen practical cooperation on refugee protection." 78

Two contemporaneous incidents involving "boat people" in transit to Australia from Indonesia in late September 2009 show that Indonesia's response at this point is not defined by compliance with Australian policy. They involved two boatloads of Sri Lankan asylum seekers detected en route to Australia from Indonesia. There had been an increased outflow of Sri Lankan Tamil asylum seekers in the region following the cessation of hostilities in mid-2009. It was claimed at the time that Australian-funded surveillance at Colombo airport was partly responsible for the large outflow of Sri Lankan asylum seekers by boat.79

The first boat, the "Jaya Lestari 5," with 255 Sri Lankans was returned to the Indonesian port of Merak by the Australian Navy following an arrangement between Australia's Prime Minister Rudd and the Indonesian president. These asylum seekers remained on board in Merak port for six months and refused to enter Indonesia for fear of being detained. In an interview given in mid-October 2009, Prime Minister Rudd referred to the fact that this was one of eighty-one "separate disruptions" of departing boats "in partnership with our Indonesian friends." ${ }^{\circ}$ Although the Australian government promised $\mathrm{A} \$ 50$ million to fund policing and processing of asylum seekers in Indonesia, the Indonesian government initially refused to intervene to forcibly remove the "Jaya Lestari 5 " refugees. ${ }^{81}$

The second boatload of seventy-eight Sri Lankan asylum seekers was rescued by the Australian Customs Ship, the Oceanic Viking, and taken to Bintan Island for processing in an IOM-managed detention centre. This move led to a diplomatic incident: the provincial governor would not allow the asylum seekers to disembark, and the asylum seekers refused to disembark until given assurances that their claims for refugee status and resettlement would be processed swiftly. After a stalemate of some weeks, the asylum seekers disembarked and were processed rapidly amidst outcries of favoured treatment. Although most were resettled in Australia, a small percentage were taken by other countries. The Oceanic Viking incident in particular led to political turmoil for Prime Minister Rudd.
Following these incidents, the number of boat people arriving in Australian waters increased to the extent that by early 2010 Christmas Island, which was being used for offshore processing, was at 95 per cent capacity. During 200910 period, 2,727 boat people arrived in Australian waters. ${ }^{82}$ The offshore processing on Christmas Island, dubbed the "Indian Ocean Solution," was becoming intractable. As a consequence of Indonesia's recalcitrance, the Labor government turned to another solution.

\section{Unintended Consequences: The Australia-Malaysia Agreement 2011}

In contrast to Indonesia's prevarication in response to Australian pressure in 2009, the Australia-Malaysia Agreement 2011, which is described in this section is an example of an asymmetric power relationship, frames Australia as a regional hegemon. The arrangement was intended to deter asylum seekers intending to travel to Australia, but also to alleviate Malaysia's refugee problem as the site of one of the largest "protracted refugee situations" in Southeast Asia. Essentially it was a trade in refugees, intended to swap refugees under Australia's control for some of Malaysia’s "protracted" refugees.

On 25 July 2011 an Arrangement between the Government of Australia and the Government of Malaysia on Transfer and Resettlement (the Arrangement) was concluded by the Labor government. This bilateral agreement made under the Bali Process was for the exchange of 800 asylum seekers arriving "irregularly" by boat in Australian excised territory, ${ }^{83}$ with up to 4,000 recognized refugees awaiting resettlement in Malaysia. By a majority of 6:1 the High Court in Plaintiffs M70/2011 and M106/2011 ${ }^{84}$ decided that the declaration was an invalid exercise of power. An important aspect of this arrangement was the designated roles of two institutions: IOM and UNHCR.

Under the arrangement, a transferee from Australia, "if determined to be a refugee ... will be referred to resettlement countries pursuant to UNHCR's normal processes and criteria." 85 That is, there was no expectation created that the asylum seeker would be resettled in Australia. However, clause 5 of the arrangement specified that up to 4,00o refugees registered with UNHCR in Malaysia would be considered for resettlement in Australia. Under the arrangement, it was intended that IOM and the UNHCR would have significant roles. Indeed clause 3 stated, "This Arrangement will proceed on the basis that UNHCR and the International Organization for Migration (IOM) can fulfill the roles and functions envisaged in the Operational Guidelines at Annex A."

The Operational Guidelines ${ }^{86}$ to the Arrangement anticipated that the care of asylum seekers in Malaysia would be the responsibility of IOM and UNHCR. This was ultimately 
fatal to the legality of the declaration of the minister for immigration under the Migration Act when he declared that Malaysia was (effectively) a "safe third country" for the purpose of implementing the Arrangement. On the facts, in light of the terms of the Migration Act, the High Court decided (essentially) that the minister could not have reasonably made that decision. In essence the High Court upheld the principle that the refugees from Christmas Island remained Australia's responsibility, which Australia could not offload to non-state/interstate actors. ${ }^{87}$ Moreover if Australia was to transfer its responsibility to another state, it had to ensure that "effective" state protection was accessible. ${ }^{88}$ This was patently not the case with Malaysia.

This was a situation where resettlement was proposed for strategic purposes but in contrasting circumstances to the Indonesian situation. Whereas the RCA and other laws and policies acknowledge the presence and roles of IOM and UNHCR in Indonesia, within Malaysia their status and role is more precarious. For example, recently the Malaysian government directed the UNHCR not to register any further refugees; Malaysia does not officially recognize IOM. The Malaysia Arrangement was an example of a regional bilateral agreement involving the use of superior bargaining power by Australia.

\section{The Andaman Sea Crisis: Indonesia Engages with the Region}

From about 2008, there was an escalation of departures of the Rohingya from Myanmar and pushbacks by the Thai navy, ${ }^{89}$ which led to the revival of the Bali Process in 2009. In 2012 Surin Pitsuwan, ASEAN secretary-general (2008-12), urged ASEAN to act collectively, as it had done during the Indochinese refugee crisis (CPA). However neither ASEAN nor the Bali Process tackled the issue at this point. As the crisis escalated, in an apparent show of independence, in 2013 Indonesia convened with UNHCR, a Special Conference on Addressing Irregular Movement of People outside the Bali Process. ${ }^{90}$ In a statement at the conference, Volker Turk expressed UNHCR's concerns with regional deterrence and pushback practices, which were modelled on Australian policies. The ensuing Jakarta Declaration on Addressing Irregular Movement of Persons pledged countries of origin, transit, and destination to work together to address irregular migration..$^{91}$

In this final section I show that a defining moment in the Australia-Indonesia relationship was the rejection of Australia's pushback policies by regional and international actors (including Indonesia) in responding to the Rohingya "crisis" in Southeast Asia in May 2015. ${ }^{92}$ Moreover Indonesia engaged with Malaysia and Thailand to end a stalemate on the crisis. More recently, Indonesia adhered to its rejection of pushback policies by permitting a group of Sri Lankan asylum seekers who had failed to reach Australia to land on Aceh to be assessed under the RCA. 93

\section{Regional Response to the Crisis}

Estimates differ but some suggest that as many as 6,500 persons departed from Myanmar and Bangladesh mainly by boat in 2015. ${ }^{94}$ In May 2015 the discovery of twenty-six bodies in a mass grave of smuggled Rohingya in a trafficking camp in southern Thailand 95 signalled the urgent need to tackle this situation. This led to attempts to push the "blame" for the crisis onto Thailand for failing to solve the trade and "trafficking" of "illegal immigrants." At this point states in the region (Indonesia, Thailand, and Malaysia) continued pushbacks of boats carrying the Rohingya people and called for the "richer" countries to settle the refugees.

A couple of "circuit breakers" arose when it became clear that the international community was not rushing to the rescue. The first was a statement by the Philippines government on 18 May that it would not push back the Rohingya but would shelter up to 3,000 people. The second was more symbolic. On 19 May 2015 a group of fishermen from Aceh defied the Indonesian government's pushback policy and rescued a group of "boat migrants." A tone of moral high ground also entered the debate when parallels between Australia's pushback policy and the regional response were drawn. One commentator referred to the "pernicious influence" of Australia's "stop the boats" policy. ${ }^{96}$

From that point the three most affected states (Indonesia, Thailand, and Malaysia) began to work cooperatively to broker a solution to the crisis. The ministers of foreign affairs of Malaysia, Indonesia, and Thailand met on 20 May 2015 ahead of an international meeting on 29 May, to discuss the issue of "irregular movement of people" into Indonesia, Malaysia, and Thailand. It was stated that the purpose of the meeting was for "finding a solution to the crisis of influx of irregular migrants and its serious impact on the national security of the affected countries." 97 The joint statement issued following the meeting of 20 May 2015 asserted that these three states had taken "necessary measures ... on humanitarian grounds, beyond their international obligations,"98 as "the issue cannot be addressed solely by these three countries." In their statement the states appealed to ASEAN and to the "spirit of unity and solidarity of ASEAN," to play an active role in addressing the issue. They asserted the need to address the "root causes. The ministers pledged to uphold their "responsibilities and obligations under international law and in accordance with their respective domestic laws, including the provision of humanitarian assistance to ... those 7,000 irregular migrants still at sea."99 They agreed to offer them temporary shelter, "provided that the resettlement and 
repatriation process will be done in one year by the international community." Malaysia and Indonesia invited other countries in the region "to join in this endeavour."

The seventeen recommendations in the 29 May statement by states following the Special Meeting on Irregular Migration $^{100}$ largely endorse those of 20 May. They focus upon preventing irregular migration and responding to the issue of "human trafficking" and "people smuggling" rather than lasting solutions. Only the final recommendation (q), which referred to root causes and improving livelihoods in "at-risk communities," alluded to the protection needs of the Rohingya.

The outcome of the 29 May meeting was condemned by human rights advocates who pointed to the failure to provide asylum procedures and durable solutions. ${ }^{101}$ The current situation of the Rohingya refugees supports this critique. A year later, a number of commentators took stock of the issue. ${ }^{102}$ According to a number of reports, although the regional government of Aceh (Indonesia) took in about 1,0oo Rohingya, by early 2016 only about 400 remained. This was attributed to Aceh's ad hoc response to refugee protection. In contradiction to national policy, this cohort of asylum seekers was detained in camps under poor conditions. Gradually many moved to Malaysia. There it is reported that of about 1,100 Rohingya, 50 have been resettled to third countries, 670 returned home, and about 400 remain in detention. The crisis appears not to have improved protection outcomes or norms in the region. In April 2016 Thailand blocked an effort by a private enterprise to continue to rescue migrants at sea, after it had rescued about 13,000 migrants at sea. ${ }^{103}$

In this context ASEAN remained passive, but the Bali Process was finally reconvened in March 2016 to formulate an "urgent and collective response" in the form of a new Bali Declaration on People Smuggling, Trafficking in Persons and Related Transnational Crime. ${ }^{104}$ In the lead up to this meeting a number of commentators urged the Bali Process to "step up" to the challenge of regional refugee protection. ${ }^{105}$ However the focus of the 2016 Declaration is upon "transnational organised crime." For example, it is ingeniously stated in paragraph 2, "The decline in irregular movement of persons in these waters in the second half of 2015, [is] attributable to the resolute actions by affected countries to disrupt smuggling networks, among other factors."

Although the 2016 Declaration recognizes the need "to identify and provide safety and protection" and to "address the root causes," the focus of the measures is on "irregular migrants" and "mixed migratory movements."106 Concrete measures suggested are to "enhance safe and orderly migration pathways, including for migrant workers," but for refugees the states are merely encouraged to "explore potential temporary protection and local stay arrangements for asylum seekers and refugees, subject to domestic laws and policies of member states."107

In this respect the Declaration acknowledges "the need for adequate access to irregular migrants wherever they are, by humanitarian providers especially the UNHCR and the IOM, as appropriate." 108

The Declaration was badged as Australia's initiative ${ }^{109}$ "to counter this terrible trade in human beings." But Indonesia's reaction to it shows the gap between the two countries. As mentioned above, one consequence of Australian policies is the increase in asylum seekers in Indonesia in need of resettlement in third countries. In commenting on the Declaration, Indonesian Foreign Minister Retno Marsudi called for countries to assist with the resettlement of the more than 13,000 refugees and asylum seekers registered with the UNHCR in Indonesia. She said, "Of course there is hope from Indonesia not only to Australia but to every country to be more receptive to these migrants who have been waiting for resettlement."110 But the Declaration makes no reference to resettlement outcomes.

\section{Conclusions}

For the purpose of examining the proposition that Australia is a regional hegemon on refugee issues, I examined Australian-Indonesian cooperation over three periods to demonstrate that it is not explained primarily by power asymmetry and acquiescence with Australia's "burden-shifting" measures; the metaphor of "incentivised policy transfer" is an incomplete explanation for Indonesia's apparent cooperation with Australia's deterrent policies.

I have shown that in the first period, 2001-8, the relationship is characterized by Indonesia's conflicted response: tolerance of refugee protection is tempered by pragmatic acquiescence to the demand for increasingly securitized measures by Australia. In the second period, 2008-13, the relationship becomes more complex and Indonesian responses more fragmented, so that it is indeed difficult to describe an Indonesian response. This is because regional, private, non-state, and interstate actors are involved. In the final period covering the Rohingya crisis in the region, Indonesia separates itself from Australian influence and displays more connection with the region on resolution of the crisis. Moreover, it continues, albeit in a shaky way, its policy of tolerant protection. In this crisis the consequences of Australia's policies on Indonesia's refugee "problem" and the differences between the needs of the two countries become apparent. Indonesia's current focus is on its own needs and those of the region. ${ }^{11}$

Several features of the Indonesia-Australia relationship become clear through close analysis of their cooperative relationship on transit refugees. First, Indonesia does not do Australia's bidding on all occasions, and when it does, it is 
probably motivated as much by self-interest and other factors that reflect its geopolitical position, ${ }^{112}$ as by maintaining good relationships with Australia. Indonesia's comparatively passive response to Australian policy contrasts with its proactive role in ASEAN forums. As I heard one Indonesian official say at a seminar on human trafficking held in Bandung in November 2012, Indonesia is more interested in policing its northern waters and trading routes than in its southern or Australia-oriented waters. Second, although there is Indonesian national law and policy on refugee protection, it is difficult to assume that there is a united Indonesian response to refugees or to Australian pressure, as events in 2009 demonstrated. Further, Aceh's response to Rohingya refugees demonstrates the fragmented nature of the Indonesian state in realist terms. These facts weaken the argument that Australia is a hegemon in the Indonesia-Australia relationship.

In this article, referring to Thomas Pedersen's concept of "cooperative hegemony," which focuses upon "ideationalinstitutional realism" and using the example of IndonesiaAustralia cooperation on transit refugees, I have argued against Australia's presentation of itself as a leading power or hegemon and "norm entrepreneur" on refugee and asylumseeker issues.

The Bali Process is the main institution through which Australia can assert its role as a regional hegemon and under the Indonesia-Australia relationship. But as the 2016 Bali Declaration on People Smuggling demonstrates, it appears to be the facilitator/enabler of Australian policy focused on transnational organized crime and mixed migratory movements rather than on refugee protection. It represents an "institutional gap" rather than a hegemonic institution. The recent episode involving Sri Lankan asylum seekers on Aceh shows the yawning gap between Indonesian and Australian responses to refugees under the Bali Process. Moreover, on refugee issues the 2016 Bali Declaration acknowledges the need to pursue refugee protection through international non-state and interstate actors. This fact is also recognized in the RCA, which governs the Indonesia-Australia cooperation.

Turning to the regional institutional framework and situation, it is clear that both ASEAN and its member states failed to promote lasting solutions during the Andaman Sea crisis. Despite the promise of the ADHR, state responses show that permanent refugee protection, at least in the form of resettlement outcomes, is seen to be the responsibility of the international community.

Another important aspect of the situation challenges the idea of "cooperative hegemony" in realist terms. I have demonstrated an increasing tendency for states in the region to pursue refugee protection through international non-state and interstate actors. Rather than being a model of "cooperative hegemony," the Bali Process reveals through the 2016
Declaration, and in the Australia-Indonesia RCA cooperation relationship, the "institutional space"113 that is filled by the UNHCR and IOM.

\section{Notes}

1 Thomas Pedersen, "Cooperative Hegemony: Power, Ideas and Institutions in Regional Integration," Review of International Studies 28, no. 4 (2002): 677-96.

2 Alexander Betts, Protection by Persuasion: International Cooperation in the Refugee Regime (Ithaca, NY: Cornell University Press, 2009).

3 United Nations Convention Relating to the Status of Refugees 1951, 189 UNTS 137 .

4 Amy Nethery and Carly Gordyn, "Australia-Indonesia Cooperation on Asylum Seekers: A Case of 'Incentivised Policy Transfer," Australian Journal of International Affairs 68, no. 2 (2013): 181.

5 Thomas Gammeltoft-Hansen and James C. Hathaway, "Non-Refoulement in a World of Cooperative Deterrence," Columbia Journal of Transnational Law 53 (2015): 235-84.

6 Ibid., 240; Nikolas Feith Tan, "State Responsibility for International Cooperation on Migration Control: The Case of Australia," Oxford Monitor of Forced Migration 5, no. 2 (2016): 8-19.

7 Nethery and Gordyn, "Australia-Indonesia Cooperation," 68.

8 The Association of Southeast Asia Nations (ASEAN), founded in 1967, originally involved five states-Singapore, Malaysia, Thailand, Philippines, and Indonesia-to promote "common political interests as well as a forum for private business and community-level interactions." See ASEAN, The ASEAN Declaration (Bangkok Declaration), Bangkok, 8 August 1967. http://asean.org/the-asean-declarationbangkok-declaration-bangkok-8-august-1967/. Brunei was added in 1984, Vietnam in 1995, Lao PDR and Myanmar in 1997, and Cambodia in 1999.

9 "The Bali Process on People Smuggling, Trafficking in Persons and Related Transnational Crime," http://www baliprocess.net.

10 See "Australia," Association of Southeast Asian Nations, http://asean.org/asean/external-relations/australia/.

11 Susan Kneebone, "The Bali Process and Global Refugee Policy in the Asia-Pacific Region," Journal of Refugee Studies 27, no. 4 (2014): 596-618.

12 Melissa Curley and Kahlia Vandyk, "The Securitisation of Migrant Smuggling in Australia and Its Consequences for the Bali Process," Australian Journal of International Affairs (2016): 2, http://www.tandfonline.com/doi/abs/10.108o/103 57718.2016.1181149?.journalCode $=$ caji2o.

13 "International Conference on Indo-Chinese Refugees, Geneva, 13-14 June 1989: Declaration and Comprehensive Plan of Action," Un Doc A/CONF, 148/2, 13 June 1989.

14 Susan Kneebone and Felicity Rawlings-Sanaei, eds., "Old and New Regionalism," New Regionalism and Asylum 
Seekers: Challenges Ahead (Oxford: Berghahn Books, 2007), 11-18; Susan Kneebone and Sharon Pickering, "Australia and the Pacific Region," in Kneebone and Rawlings-Sanaei, New Regionalism and Asylum Seekers, 167-87.

15 Kneebone and Rawlings-Sanaei, "Old and New Regionalism."

16 Antje Missbach, Troubled Transit: Asylum Seekers Stuck in Indonesia (Singapore: ISEAS Yusof Ishak Institute, 2015), 29-41.

17 Presidential decree no. 38/1979 regarding Coordination of the Resolution of Issues Related to Vietnamese Refugees in Vietnam. See Savitri Taylor and Bryanna Rafferty-Brown, "Difficult Journeys: Accessing Refugee Protection in Indonesia," Monash University Law Review 36 (2010): 144n33.

18 Cat Barker, "The People Smugglers' Business Model," Parliament of Australia, Department of Parliamentary Services, Research Paper no. 2. 2012-13 (28 February 2013), 37.

19 United Nations High Commissioner for Refugees (UNHCR) Thailand. https://www.unhcr.or.th/en.

20 UNHCR, "Global Focus: Thailand," http://reporting.unhcr .org/node/2552?y=2015\# objectives.

21 UNHCR Malaysia, "Figures at a Glance," http://www.unhcr .org.my/about_us-@-figures_at_a_glance.aspx.

22 Sriprapha Petcharamesree, "ASEAN and Its Approach to Forced Migration Issues," International Journal of Human Rights 20, no. 2 (2016): 173-9o.

23 Susan Kneebone, "ASEAN and the Conceptualisation of Refugee Protection," in Regional Approaches to the Protection of Asylum Seekers: An International Legal Perspective, ed. Francesca Ippolito and Ademola Abass, 295-324 (Oxford: Routledge, 2014).

24 ASEan, ASEAN Political-Security Community Blueprint (Jakarta: ASEAN Secretariat, 2009), para. 9, http://asean .org/wp-content/uploads/archive/5187-18.pdf.

25 Matthew Pomy, "ASEAN Adopts Human Rights Declaration," Jurist, 18 November 2012, http://jurist.org/paperchase/2012/11/asean-adopts-human-rights-declaration.php.

26 Felix Heiduk, "Indonesia in ASEAN: Regional Leadership between Ambition and Ambiguity," swp Research Paper, Berlin, RP 6, April 2016.

27 Susan Kneebone, "Migration Control at Sea: The Australian Case," in Extraterritorial Immigration Control: Legal Challenges, ed. Bernard Ryan and Valsamis Mitsilegas (Leiden: Martinus Nijhoff, 2010), 349.

28 Susan Kneebone and Sharon Pickering, "Australia, Indonesia and the Pacific Plan," in Kneebone and RawlingsSanaei, New Regionalism and Asylum Seekers, 178; Missbach, Troubled Transit, 180 .

29 Kneebone, "Migration Control at Sea," 356-6o.

30 Kneebone and Pickering, "Australia, Indonesia and the Pacific Plan."

31 Kneebone, "Migration Control at Sea," 361.

32 Ibid., 362.

33 Susan Kneebone, "The Australian Story: Asylum Seekers outside the Law," in Refugees, Asylum Seekers and the Rule of Law, ed. Susan Kneebone (Cambridge: Cambridge University Press, 2009), 195-7.

34 Kneebone, "Migration Control at Sea," 369n103.

35 Taylor and Rafferty-Brown, "Difficult Journeys," 147n52.

36 Amy Nethery, Bryanna Rafferty-Brown, and Savitri Taylor, "Exporting Detention: Australia-Funded Immigration Detention in Indonesia," Journal of Refugee Studies 26, no. 1 (2013): 95 .

37 Ibid.

38 Ibid., 95-7.

39 Australian Government, Department of Immigration and Citizenship, Annual Report: 2006-07, 77, http://www.border gov.au/ReportsandPublications/Documents/annualreports/annual-report-2006-07-complete.pdf.

40 Ibid., 78.

41 Kneebone, "Bali Process and Global Refugee Policy," 596-618.

42 Caroline Millar, “Bali Process': Building Regional Cooperation to Combat People Smuggling and Trafficking in Persons," speech by the Australian Ambassador for People Smuggling Issues, Institute for the Study of Global Movements, Monash University, Melbourne, 29 July 2004, http:// dfat.gov.au/news/speeches/Pages/bali-process-buildingregional-cooperation-to-combat-people-smuggling-andtrafficking-in-persons.aspx.

43 Ibid.

44 Kneebone, "Bali Process and Global Refugee Policy."

45 Ibid., 603.

46 Circular Letter of the Prime Minister no. 11/R.I/1956 of 1956 on Political Refugees, 7 September 1956.

47 Kneebone, "ASEAN and the Conceptualisation of Refugee Protection."

48 Pene Mathew and Tristan Harley, "Refugee Protection and Regional Cooperation in Southeast Asia: A Fieldwork Report," Canberra: Australia National University, March 2014, http://www.mcrg.ac.in/wC_2015/Reading/D_RefugeeProtection.pdf.

49 Enny Soeprapto, "Promotion of Refugee Law in Indonesia," Indonesian Journal of International Law 2, no. 1 (2004): 57.

50 UN Convention against Torture signed 23 October 1985, ratified 28 October 1998. International Covenant on Civil and Political Rights ratified 23 February 2006. Entered into force 23 May 2006.

51 Circular of the Director General of Immigration, Department of Justice, no. F-IL.10-1297, 30 September 2002 regarding Procedures regarding Aliens Expressing Their Desire to Seek Asylum or Refugee Status.

52 Directive of the Director General of Immigration, regarding Handling of Irregular Migrants, no. IMI-1489.UM.08.05 YEAR 2010.

53 Soeprapto, "Promotion of Refugee Law," 57.

54 Ibid., 64.

55 Bilal Dewansyah, "Asylum Seekers in a Non-Immigrant State and the Absence of Regional Asylum Seekers Mechanisms: A Case Study of Rohingya Asylum Seekers in Aceh,"

(C) Susan Kneebone, 2017. This open-access work is licensed under a Creative Commons Attribution-NonCommercial 4.0 International License, which permits use, reproduction and distribution in any medium for non-commercial purposes, provided the original author(s) are credited and the original publication in Refuge: Canada's Journal on Refugees is cited. 
paper presented to 5th AsiansIL Biennial Conference 2015, Bangkok, November 2015, 9.

56 Klaus Neumann and Savitri Taylor, "Australia, Indonesia and West Papuan Refugees, 1962-2009," International Relations of the Asia-Pacific 10 (2009): 1-31.

57 Barker, "People Smugglers' Business Model."

58 Natalie Klein, "Assessing Australia's Push Back the Boats Policy under International Law: Legality and Accountability for Maritime Interceptions of Irregular Migrants," Melbourne Journal of International Law 15, no. 1 (2014): 1.

59 Parliament of Australia, The Senate, Foreign Affairs, Defence and Trade References Committee, "Breaches of Indonesian Territorial Waters," March 2014.

60 Former prime minister Tony Abbott took the position that Australians were "sick of being lectured to by [the] un." See Danuta Kozaki, "Abbott Says Australians 'Sick of Being Lectured to by UN' after Scathing Report on Asylum Policies," АBC, 9 March 2015, http://www.abc.net.au/ news/2015-03-09/tony-abbott-hits-out-united-nationsasylum-report/6289892.

61 Curley and Vandyk, "Securitisation of Migrant Smuggling," 17.

62 These incidents occurred in May and November 2015. Amnesty International, "By Hook or by Crook: Australia's Abuse of Asylum-Seekers at Sea," London, Amnesty International, 2015. https://www.amnesty.org/en/documents/ ASA12/2576/2015/en/.

63 Nethery, Rafferty-Brown, and Taylor, "Exporting Detention," 94.

64 In the 2015 report UNHCR reported that was funded for only 6 per cent of its needs in Indonesia. Department of Immigration and Border Protection, Annual Report 201415, http://www.border.gov.au/about/reports-publications/ reports/annual/immigration-2014-15.

65 Australian Government, Department of Immigration and Citizenship, AnnualReport:2008-09,154,http://www.border .gov.au/ReportsandPublications/Documents/annualreports/annual-report-2008-09-complete.pdf. See also Missbach, "Troubled Transit." 137.

66 International Organisation for Migration (IOM) Indonesia, "Alternatives to Detention," https://www.iom.int/files/live/ sites/iom/files/Country/docs/Iom-Indonesia_Alternativesto-detention-September-2014.pdf.

67 Missbach, "Troubled Transit," 140-2.

68 Ibid., 142.

69 See Antje Missbach, "Doors and Fences: Controlling Indonesia's Porous Borders and Policing Asylum Seekers," Singapore Journal of Tropical Geography 35, no. 2 (2014): 1.

70 Melissa Crouch and Antje Missbach, "Trials of People Smugglers in Indonesia: 2007-2012," CILIs Policy Paper 2013, http://law.unimelb.edu.au/_data/assets/pdf_file/ooo4/ 1547824/Crouch_Missbach_web.pdf.

71 Graeme Hugo, George Tan, and Caven Jonathan Napitupulu, "Indonesia as a Transit Country in Irregular
Migration to Australia," Australian Government, Department of Immigration and Border Protection, 2014, 10.

72 Misbach, "Troubled Transit," 209-33.

73 Antje Missbach, "Sentencing People-Smuggling Offenders in Indonesia," CILIs Policy Paper 2016, http://law.unimelb .edu.au/_data/assets/pdf_file/o005/2065559/CILIs-PolicyPaper-12-Missbach_FINAL_Web.pdf.

74 Missbach, "Doors and Fences."

75 Barker, "People Smugglers' Business Model," 29.

76 Matthew Gibney, "Forced Migration, Engineered Regionalism and Justice between States," in Kneebone and Rawlings-Sanaei, New Regionalism, 57-79.

77 Kneebone, "Bali Process and Global Refugee Policy," 601-2.

78 "Bali Process on People Smuggling."

79 Matt Wade, "Australian-Funded Cameras Linked to Rise in Boat People to Sri Lanka," Age, 28 October 2009.

80 Paul Kelly, "Rudd's Softer Stance Mugged by Reality," Weekend Australian, 17-18 October 2009, 11.

81 The asylum seekers were eventually forcibly removed into a detention centre. Some then voluntarily returned to Sri Lanka (where they were arrested), while others stayed in Indonesia on the advice of both IOM and UNHCR. See "Three Tamil Refugees Disappear after Forcibly Returned to Sri Lanka," Green Left Weekly, 7 October 2010, https:// www.greenleft.org.au/node/45634.

82 Editorial comment, Age, 7 January 2010, 10.

83 See "Australia Migration Zone," Wikipedia, https:// en.wikipedia.org/wiki/Australian_migration_zone.

84 Plaintiff M7o/2011 v Minister for Immigration and Citizenship; and Plaintiff M106 of 2011 v Minister for Immigration and Citizenship, [2011] HCA 32.

85 Arrangement between the Government of Australia and the Government of Malaysia on Transfer and Settlement (Australia-Malaysia Arrangement), 25 July 2011, clause 8, http://www.kaldorcentre.unsw.edu.au/sites/default/files/ arrangement-australia-malaysia-transfer-resettlement.pdf.

86 Annex A to the Arrangement: Operational Guidelines to Support Transfers and Resettlement ("Operational Guidelines").

87 Importantly the Migration Act has been amended to broaden the discretion of the minister for immigration to declare a country as "safe" for the removal of asylum seekers.

88 Tamara Wood and Jane McAdam, "Australian Policy All at Sea: An Analysis of Plaintiff M7o/2011 v Minister for Immigration and Citizenship and the Australia-Malaysia Arrangement," International and Comparative Law Quarterly 61, no. 2 (2012): 274-30o.

89 Susan Kneebone, "Comparative Regional Protection Frameworks for Refugees: Norms and Norm Entrepreneurs," International Journal of Human Rights 20, no. 2 (2016): 153-72.

90 Kneebone, "Bali Process," 601. 
91 Jakarta Declaration on Addressing Irregular Movement of Persons, Jakarta, 20 August 2013, http://www.unhcr .org/5214ae709.pdf.

92 Michael Gordon, "People Smuggling: 'Step Up or Step Aside,' Australia and Indonesia Warned," Sydney Morning Herald, 1 February 2016, http://www.smh.com.au/world/ people-smuggling-step-up-or-step-aside-australia-andindonesia-warned-20160131-gmi1go.html.

93 "Asylum Seekers off Aceh to Be Assessed," sBs, 21 June 2016, http://www.sbs.com.au/news/article/2016/06/21/asylumseekers-aceh-be-assessed.

94 Sriprapha Petcharamesree, Peter Hughes, Steven Wong, Travers McLeod, and Tri Nuke Pudjiastuti, "The Andaman Sea Refugee Crisis a Year On: Is the Region Better Prepared?" Conversation, 27 May 2016, https://theconversation .com/the-andaman-sea-refugee-crisis-a-year-on-is-theregion-now-better-prepared-59687.

95 Silvia Di Gaetano, "How to Solve Asia's Refugee Crisis: Steps Can and Should Be Taken to Alleviate the Plight of Rohingya," Diplomat, 28 September 2015.

96 Mathew Davies, "The Rohingya and Our Rule-Bending Arrogance," Drum, 18 May 2015, http://www.abc.net.au/ news/2015-05-18/davies-rohingya-and-our-rule-bendingarrogance/6477148.

97 Ministry of Foreign Affairs, Malaysia, "Joint Statement: Ministerial Meeting on Irregular Movement of People in Southeast Asia," https://www.kln.gov.my/archive/content .php? $\mathrm{t}=3$ \&articleId $=5202813$.

98 Emphasis added.

99 Emphasis added.

100 Ministry of Foreign Affairs of the Kingdom of Thailand, "Summary, Special Meeting on Irregular Migration in the Indian Ocean, 29 May 2015, Bangkok, Thailand," http://www. $\mathrm{mfa}$.go.th/main/en/media-center/14/5688o-SummarySpecial-Meeting-on-Irregular-Migration-in.html.

101 Asia Pacific Refugee Rights Network, “APPRN Statement on Maritime Movements in the Indian Ocean," 12 October 2015, http://aprrn.info/wp-content/uploads/2015/10/ APRRN-Statement-on-Protection-at-Sea.pdf. See also "Joint NGO Statement ahead of the Special Meeting on Irregular Migration in the Indian Ocean, Bangkok, 29 May 2015," http://www.savethechildren.org.uk/2015-05/joint-ngostatement-ahead-special-meeting-irregular-migrationindian-ocean-bangkok-29-may.

102 Petcharamesree et al," "Andaman Sea Refugee Crisis."

103 Oliver Holmes, "Thailand Disrupts Attempt to Launch Migrant Rescue Ship Operation," Guardian, 14 April 2016, https://www.theguardian.com/world/2016/apr/14/thailandblocks-migrant-rescue-ships-operations-in-andaman-sea.

104 Bali Declaration on People Smuggling, Trafficking in Persons, and Related Transnational Crime (Bali Declaration), 23 March 2016.

105 Gordon, "People Smuggling." Sriprapha Petcharamesree, Peter Hughes, Steven Wong, Travers McLeod, and Tri Nuke Pudjiastuti, "The Bali Process Can Do a Lot More to Respond to Forced Migration in Our Region," Conversation, 21 March 2016, https://theconversation.com/the-baliprocess-can-do-a-lot-more-to-respond-to-forced-migration-in-our-region-56213.

106 Bali Declaration, para. 5.

107 Ibid., para 6.

108 Ibid.

109 Jewel Topsfield, "Migrant Crisis: Australia to Launch AntiHuman Trafficking and Slavery Strategy," Sydney Morning Herald, 21 March 2016, http://www.smh.com.au/world/ migrant-crisis/migrant-crisis-australia-to-launch-antihumantrafficking-and-slavery-strategy-20160321-gnnm3i.html.

110 Ibid.

111 Curley and Vandyk, "Securitisation of Migrant Smuggling," 17.

112 Missbach, "Troubled Transit," 155, states that "given Indonesia's significance in the region Australia needs Indonesia more than Indonesia needs Australia."

113 Curley and Vandyk, "Securitisation of Migrant Smuggling," 2.

Susan Kneebone is professorial fellow and associate at the Asian Law Centre at Melbourne Law School, Melbourne University. The author may be contacted at susan.kneebone@ unimelb.edu.au. 